\title{
Biometry of the Skull of Wild and Farm Long-tailed Chinchilla (Chinchilla laniger, Molina, 1782)
}

\author{
Biometría del Cráneo de la Chinchilla de Cola Larga \\ (Chinchilla laniger, Molina, 1782) Salvaje y de Granja
}

Piotr Baranowski; Magdalena Wróblewska; Piotr Nowak \& Katarzyna Pezinska

BARANOWSKI, P.; WRÓBLEWSKA, M.; NOWAK, P. \& PEZINSKA, K. Biometry of the skull of wild and farm long-tailed chinchilla (Chinchilla laniger Molina, 1782). Int. J. Morphol., 31(3):1003-1011, 2013.

SUMMARY: This study aimed at presenting the values of 47 metric traits and 20 cranial indices of the skull of 291 mature farm chinchillas and comparing these data with those being determined on 32 chinchilla skull specimens from the Natural History Museum in London. Measurements of the viscerocranium, neurocranium and mandible parameters were taken. No normal distribution of these traits was observed. The values of selected Spearman's rank correlation coefficients were calculated. It was found that most cranial traits of the farm chinchillas showed statistically significantly higher values $(\mathrm{P} \leq 0.01)$ when compared to those being determined on the skulls of museum specimens. The effect of the farm environment, in which the farm chinchillas had been kept for many generations, was a likely reason for these differences.

KEY WORDS: Biometry; Chinchilla; Viscerocranium; Neurocranium; Skull.

\section{INTRODUCTION}

Studies of the skull morphometry have been performed on different species of wild animals (Mazák \& Groves 2006; Onar et al., 2005; Sarma, 2006; Zhu, 2012), farm animals (Jakubowski et al., 2008; Parés et al., 2010) and domestic animals (Onar, 1999; Baranowski, 2010) and covered different stages of evolution and ontogenesis. Among the reports on the skull morphometry, however, there is no information on the skull anatomy of the long-tailed chinchilla, a rodent species that has been farmed for fur for about one hundred years. Its wild form is known to exists today, as an endemic species, only in a small area in inaccessible parts of the Andes Mountains in Chile (Mohlis, 1983). In addition, this population is threatened with extinction and thus all information about the morphology of the head phenotype, i.e. the shape of skull and interrelations between its respective parts of the wild and farm forms, are of taxonomic and comparative importance.

The long-tailed chinchilla (Chinchilla laniger, Molina, 1782) is a rodent belonging to the suborder Hystricomorpha, occurring today under natural conditions only in one of the national parks in Chile. It is closely related to coypus, guinea pigs and viscachas (Hoefer, 1994). Common characteristics of the anatomy of this group are foetal membranes, anatomical details of the cardiovascular system, structure of teeth and cerebral fissures (Redford \& Eisenberg, 1992). The features separating the Hystricomorpha group from other rodents are very large orbit with the attachments of masticatory muscles, different anatomy of the mandible and different position of the lacrimal bone, as well as the junctions of the parietal, temporal and occipital bones (Lavocat, 1974). The course of cerebral vessels in chinchillas points to significant taxonomic separateness of this species among rodents (Jablonski \& Brudnicki, 1984; Roskosz et al., 1988).

Domestication exerts a lasting effect on the anatomy and functions of animal organisms and their behaviour (Zeuner, 1963; Clutton-Brock, 1999) but changes can also appear in the animals being captured and kept in captivity for one or several generations (O'Regan \& Kitchener, 2005). Morphological changes in animals are also affected by ecological relations of the natural ecosystems where animals live (Zuccarelli, 2004). Farm environment creates specific 
conditions of living for animals. For example, the number of individuals with pathological teeth may increase in the population of chinchillas being kept under farm conditions, even when maintaining all good animal welfare standards (Crossley et al., 1998; Crossley, 2001; Crossley \& Miguelez, 2001). Pathological teeth may be a source of changes in the skull anatomy and differences in the values of craniometric traits (Baranowski et al., 2008) as well as a cause of the asymmetry of non-metric (epigenetic or discrete) traits being found on crania and mandibles (Baranowski \& Wojtas, 2011a, 2011b).

The aim of this study was to present the values of metric traits of the skull of chinchillas being kept under farm conditions and compare the results of this analysis with the values of the same traits being determined on the skulls of chinchillas being captured in their natural living environment.

\section{MATERIAL AND METHOD}

The study was carried out on the crania and mandibles of mature long-tailed chinchillas (Chinchilla laniger, Molina, 1782) of two groups: group I - representing wild animals (n $=32$ ), from Chile and Bolivia and collected at the end of the $19^{\text {th }}$ century and at the beginning of the $20^{\text {th }}$ century, being made available by courtesy of the Natural History Museum in London, and group II - representing farm animals ( $\mathrm{n}=$ 291), from carcasses being skinned on a chinchilla farm in Poland $\left(53^{\circ} 40^{\prime} \mathrm{N}, 15^{\circ} 08^{\prime} \mathrm{E}\right)$. Based on the analysis of cranial suture obliteration and comparison with the skulls of farm chinchillas of known age from Poland, it was found that museum skulls of the long-tailed chinchilla came from mature animals (sub-adult). The age of farm animals at slaughter ranged between 240 and 507 days, which was determined based on their record cards. Skull specimens with pronounced hypertrophic defects of the cranium and mandible were removed from both the museum and the farm groups and were excluded from the analysis. The skulls of farm chinchilla are being housed in the collection of the Department of Animal Anatomy, Faculty of Biotechnology and Animal Husbandry, Western Pomeranian University of Technology in Szczecin (Poland). Making use of the method of measurements developed for animal bone remains (Driesch von den, 1976), supplemented with the technique being applied in own studies (Baranowski et al.), measurements were taken on the chinchilla skulls using the reference points on their crania and mandibles. To estimate the values of chinchilla skull metric traits, an electronic calliper (Orion 31170 150) was used, with a $0.01 \mathrm{~mm}$ accuracy. Each measurements was made twice and the ave- rage of two replications was calculated. The measuring error did not exceed $3 \%$.

In the dorsal projection (Projectio dorsalis), the following parameters of the chinchilla cranium were measured:

1) Viscerocranium length: Nasion - Prosthion (N-P)

2) Neurocranium length: Nasion - Basion (N-B)

3) Facial length: Supraorbitale - Prosthion (Sp-P)

4) Profile length: Akrokranion - Prosthion (A-P)

5) Upper neurocranium length: Akrokranion - Supraorbitale (A$\mathrm{Sp})$

6) Median frontal length: Akrokranion - Nasion (A-N)

7) Frontal length: Bregma - Nasion $(\mathrm{Br}-\mathrm{N})$

8) Greatest length of the nasals: Nasion - Rhinion (N-Rh)

9) Greatest breadth across the praemaxillae Rostrum

10) Least breadth between the orbits: Entorbitale - Entorbitale (EntEnt)

11) Least breadth of the frontal: Frontale - Frontale (Ft-Ft)

12) Greatest breadth across the orbits: Ectorbitale - Ectorbitale (Ect-Ect)

13) Greatest neurocranium breadth: Eurion - Eurion (Eu-Eu)

14) Zygomatic breadth: Zygion - Zygion (Zyg-Zyg)

In the ventral and lateral projections (Projectio ventralis et lateralis), the following parameters of the chinchilla cranium were measured:

15) Length of the viscerocranium base: Praemolare - Prosthion (P-Pm)

16) Basal length: Basion - Prosthion (B-P)

17) Oral palatal length: Prosthion - Palatinoorale (P-Po)

18) Short skull length: Basion - Praemolare (B-Pm)

19) Palatal length: Akrokranion - Palatinoorale (A-Po)

20) Greatest palatal breadth

21) Length of the maxillary cheek-tooth row, measured along the occlusal surface

22) Height of the cranium from Bregma to the lowermost point of the bulla tympanica

23) Greatest inner height of the orbit

24) Greatest inner length of the orbit: Ectorbitale - Entorbitale (Ect-Ent)

On the chinchilla mandible, the following parameters were measured:

25) Length of the diastema

26) Height of the mandible in front of M1

27) Height of the mandible in front of M3

28) Breadth of the vertical ramus measured from the indentation between the condylar process and the angular process to the aboral margin of the alveolus of M3

29) Oral height of the vertical ramus: Gonion ventrale - Coronion

30) Aboral height of the vertical ramus: Gonion ventrale - highest point of the condylar process

31) Length from the angular process: aboral margin of the angular process - Infradentale 
32) Length from the angular process to the oral margin of the alveolus of P1

33) Length of the mandibular cheek-tooth row, measured along the alveoli

34) Length from Infradentale to Coronion

35) Length of the mandibular cheek-tooth row, measured along the occlusal surface.

In addition, photographs of the nuchal plane of chinchilla crania were made (Fig. 1. Nuchal view). In order to make the photographs, each cranium was positioned with its Rostrum down under a digital camera (Canon EOS-1000D with a Macro EFS60mm f/2.8 lens) being installed on a calibrated frame. The cranium position obtained this way was exactly such so as its plane being formed by the lumen area of the foramen magnum was perpendicular to the camera lens and image sensor. The photographs were then transferred to MultiScan 8.0 software which was used to determine values of the following parameters:

36) Breadth of the foramen magnum

37) Greatest breadth of the occipital condyles

38) Breadth of the occipital squama

39) Greatest breadth between paracondylar processes (a)

40) Greatest mastoid breadth: Otion-Otion (Ot-Ot)

41) Height of the foramen magnum

42) Height of the occipital squama

43) Neurocranium height measured from the highest point on the occipital bone (Akrokranion) to the point on the basal edge of the foramen magnum (Basion) (Height of the occipital triangle) (h)

44) Height of the cranium measured from Basion to Bregma.

45) Height of the cranium measured from the lowest point of the Bulla tympanica to Bregma.

Moreover, using the obtained photographs (Fig. 1.), the area of the occipital triangle (parameter 46) was calculated according to the following equation: $\mathrm{P}=\mathrm{a} \times \mathrm{h} / 2$, as well as the area of the foramen magnum (parameter 47).

The values of metric traits being obtained were used to calculate the cranial indices characterising relationships between selected skull traits:

1. Index $1=$ Height of the cranium from Bregma to the lowermost point of the bulla tympanica $\mathrm{x} 100 / \mathrm{B}-\mathrm{P}$

2. Index $2=\mathrm{Eu}-\mathrm{Eu} \times 100 / \mathrm{A}-\mathrm{Po}$

3. Index $3=\mathrm{Eu}-\mathrm{Eu} \times 100 / \mathrm{A}-\mathrm{P}$

4. Index $4=\mathrm{Ft}-\mathrm{Ft} \times 100 / \mathrm{Eu}-\mathrm{Eu}$

5. Index $5=$ Orbit height $\times 100 /$ Orbit breadth

6. Index $6=\mathrm{Br}-\mathrm{N} \times 100 /$ Ect-Ect

7. Index $7=\mathrm{N}-\mathrm{P} \times 100 / \mathrm{B}-\mathrm{P}$

8. Index $8=\mathrm{P}-\mathrm{Pm} \times 100 / \mathrm{P}-\mathrm{Po}$

9. Index $9=$ Greatest palatal breadth $\mathrm{x} 100 / \mathrm{B}-\mathrm{P}$

10. Index $10=$ Length of the maxillary cheek-tooth row, measured along the occlusal surface $\mathrm{x} 100 / \mathrm{B}-\mathrm{P}$

11. Index $11=$ Length of the diastema $\mathrm{x} 100 /$ Breadth of the vertical ramus measured from the indentation between the condylar process and the angular process to the aboral margin of the alveolus of M3

12. Index $12=$ Length of the mandibular cheek-tooth row, measured along the occlusal surface $\mathrm{x} 100$ / Breadth of the vertical ramus measured from the indentation between the condylar process and the angular process to the aboral margin of the alveolus of M3

13. Index 13 (neurocranium) $=\mathrm{Eu}-\mathrm{Eu} \times 100 / \mathrm{A}-\mathrm{N}$

14. Index $14=\mathrm{Eu}-\mathrm{Eu} \times \mathrm{x}$ 100/ B-P

15. Index 15 (viscerocranium) $=$ Zyg-Zyg x 100/ N-P

16. Index 16 (cranial) $=$ Zyg-Zyg x 100/ A-P

17. Index $17=$ Zyg-Zyg $x$ 100/ Sp-P

18. Index $18=\mathrm{Eu}-\mathrm{Eu} \times 100 / \mathrm{A}-\mathrm{Sp}$

19. Index of cranial capacity, calculated according to the following formula: A-N x Eu-Eu x Height of the skull from Bregma to the lowermost pointof the bulla tympanica

20. Foramen magnum index $=$ Height F.m. x 100 / Breadth F.m.

All the measurement results being obtained were entered into a database of Statistica v.10 PL software package where the distribution of traits was checked. Since no normal distribution of the traits was observed, differences between mean values of respective skull traits between groups were evaluated with a non-parametric MannaWhitney's U test for two independent samples. Relationships between selected skull traits were estimated using the Spearman's rank correlation coefficient. When evaluating the differences between mean values and the values of correlation coefficients, two levels of significance were used, i.e. $\mathrm{P} \leq 0.05$ and $\mathrm{P} \leq 0.01$. The analysis of data was performed assuming the skull origin (natural population and farm population) to be a source of variation. The terminology being used conforms to Veterinary Anatomical Nomenclature (Milart, 2002) and Nomina Anatomica Veterinaria (http:// www.wava-amv.org/downloads/nav_2012.pdf)

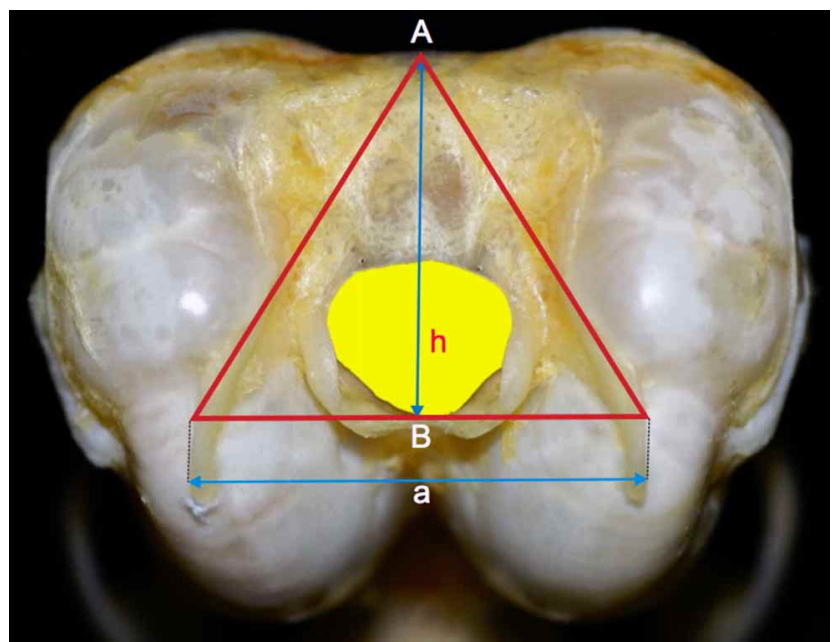

Fig. 1. Parameters of the chinchilla cranium measured. Nuchal view. 


\section{RESULTS}

Analysis of the skull measurement results showed that the crania and mandibles of farm-reared long-tailed chinchillas were significantly larger than the museum specimens (Table I). The viscerocranium and neurocranium lengths (A-N and N-P) in farm chinchilla skulls were larger by about $5 \%$ when compared to the museum ones, while the parameters describing the cranium breadth, such as the greatest neurocranium breadth $(\mathrm{Eu}-\mathrm{Eu})$ and the greatest breadth across the praemaxillae (Rostrum), were larger by about $7 \%$ and $12 \%$, respectively. The spacing of the orbits (greatest breadth across the orbits, Ect-Ect) and the least breadth of the frontal (Ft-Ft) in the crania of farm chinchillas exceeded those of the museum specimens by $2.7 \%$. The zygomatic breadth (Zyg-Zyg) of the crania of farm chinchillas exceeded, on average by $5 \%(\mathrm{P} \leq 0.01)$, the values of that parameter being determined on the museum ones. Only the length being defined by reference points Bregma and Nasion (frontal length, Br-N) did not show any significant differences between the chinchilla skull groups in question.

Table I. Values of the biometric traits of the long-tailed chinchilla skulls.

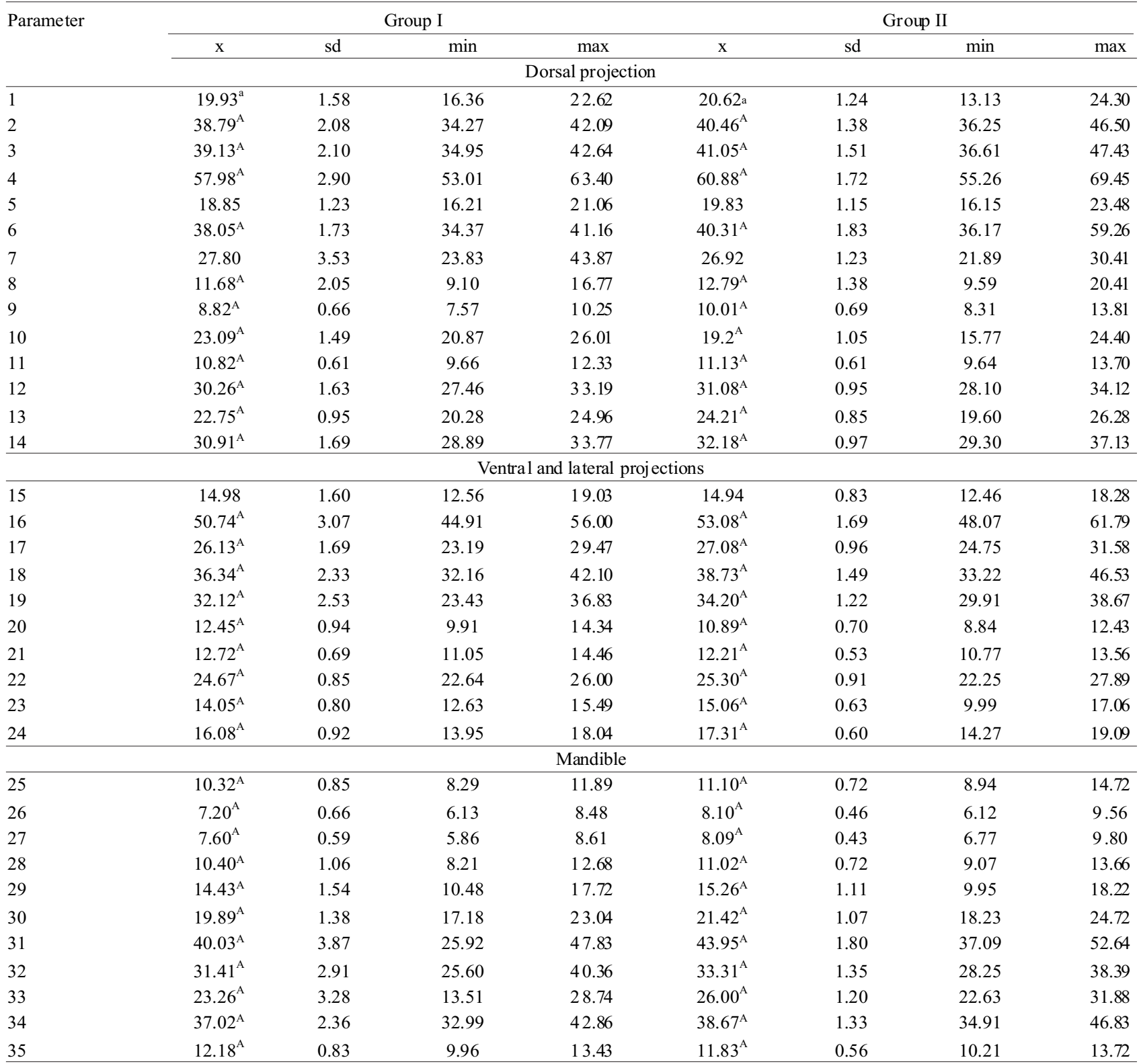

Explanations to Table I: mean values in rows marked with the same letters differ significantly at $\mathrm{P} \leq 0.01$. 
The basal length (B-P), oral palatal length (P-Po) and the palatal length Akrokranion-Palatinoorale of the crania of farm chinchillas exceeded, on average by $5 \%$ ( $\mathrm{P} \leq 0.01$ ), the values of those parameters being determined on the museum ones. Only the length of the maxillary cheek-tooth row and the greatest palatal breadth were larger by $4 \%$ in the museum crania $(\mathrm{P} \leq 0.01)$.

Mean values of the parameters of farm chinchilla mandibles were significantly larger $(\mathrm{P} \leq 0.01)$ when compared to those being determined on the museum specimens, in which only the length of the mandibular cheek-tooth row exceeded the values of that parameter of the farm specimens.

The relative values being presented in Table II in the form of cranial indices, characterizing interrelations of selected skull parts, illustrate the relationships between some parts of the crania and mandibles of both groups.

The values of correlation coefficients for selected skull traits are presented in Table III. The museum crania showed a moderate correlation $(\mathrm{rxy}=0.538 ; \mathrm{P} \leq 0.01)$ between the upper neurocranium length (A-Sp) and the facial length (Sp$\mathrm{P})$, as opposed to those of farm chinchillas in which these traits demonstrated a weak and negative correlation ( $\mathrm{rxy}=$ 0.217). The values of these correlation coefficients differed significantly $(\mathrm{P} \leq 0.01)$. Whereas the facial length $(\mathrm{Sp}-\mathrm{P})$ of the museum specimens showed a strong correlation ( $r x y=$ 0.719) with the zygomatic breadth (Zyg-Zyg), the value of correlation coefficient for these traits in the crania of farm chinchillas was lower by about $54 \%$. At the same time, attention was drawn to similar values of correlation coefficients between the greatest neurocranium breadth (Eu$\mathrm{Eu}$ ) and the zygomatic breadth (Zyg-Zyg) in both chinchilla skull groups, i.e. $\mathrm{rxy}=0.395$ for group I and $\mathrm{rxy}=0.346$ for group II. In the group of museum specimens, a negative value of correlation coefficients was also found for the neurocranium index (Eu-Eu x 100/A-Sp) and the facial length (Sp-P) $(\mathrm{rxy}=$ $-0.250)$ and the upper neurocranium length $(\mathrm{A}-\mathrm{Sp})(\mathrm{rxy}=-$ 0.794), whereas these correlation coefficients in the group of farm chinchilla skulls assumed partly opposite values, i.e. positive and weak correlation of the neurocranium index with the facial length ( $\mathrm{rxy}=0.317)$, while a negative and stronger correlation with the upper neurocranium length $(\mathrm{rxy}=-0.824)$. Furthermore, a larger number of traits with high correlation $(\mathrm{rxy}>0.600$ - rxy $<0.800)$ was observed, being characteristic of the nuchal plane of museum chinchilla crania than those of farm chinchilla ones (Table V).

Table II. Values of the craniometric indices of the long-tailed chinchilla skulls.

\begin{tabular}{|c|c|c|c|c|c|c|c|c|}
\hline \multirow[b]{2}{*}{ Index } & \multicolumn{4}{|c|}{ Group I } & \multicolumn{4}{|c|}{ Group II } \\
\hline & $\mathrm{x}$ & sd & $\min$ & $\max$ & $\mathrm{x}$ & sd & $\min$ & $\max$ \\
\hline 1 & $39.27 \mathrm{~A}$ & 2.03 & 34.82 & 42.64 & $37.54^{\mathrm{A}}$ & 1.76 & 31.90 & 57.12 \\
\hline 2 & 71.37 & 6.49 & 63.35 & 97.40 & 70.84 & 3.09 & 59.56 & 79.58 \\
\hline 3 & 39.32 & 2.03 & 35.02 & 43.63 & 39.78 & 1.55 & 33.36 & 44.53 \\
\hline 4 & $47.51 \mathrm{~A}$ & 2.74 & 41.35 & 54.34 & $46.01^{\mathrm{A}}$ & 2.52 & 39.76 & 59.29 \\
\hline 5 & 87.43 & 4.37 & 76.05 & 95.23 & 87.03 & 3.30 & 70.01 & 96.18 \\
\hline 6 & $92.37 \mathrm{~A}$ & 12.26 & 71.80 & 148.81 & $86.66^{\mathrm{A}}$ & 3.92 & 75.51 & 96.17 \\
\hline 7 & 39.27 & 1.72 & 36.71 & 42.80 & 38.86 & 2.09 & 24.38 & 46.53 \\
\hline 8 & $57.15 \mathrm{a}$ & 4.66 & 47.90 & 66.98 & $55.18 \mathrm{a}$ & 2.83 & 44.50 & 66.40 \\
\hline 9 & $24.58 \mathrm{~A}$ & 1.49 & 21.09 & 27.74 & $20.52^{\mathrm{A}}$ & 1.38 & 16.70 & 23.95 \\
\hline 10 & $25.02 \mathrm{~A}$ & 0.98 & 23.14 & 26.70 & $23.01^{\mathrm{A}}$ & 0.97 & 18.43 & 25.50 \\
\hline 11 & 99.79 & 8.82 & 83.23 & 116.77 & 101.06 & 8.60 & 77.74 & 131.12 \\
\hline 12 & $117.98^{\mathrm{A}}$ & 10.90 & 91.51 & 143.60 & $107.71^{\mathrm{A}}$ & 8.01 & 87.30 & 129.14 \\
\hline 13 & 59.90 & 3.11 & 53.82 & 66.15 & 60.14 & 2.85 & 42.93 & 68.84 \\
\hline 14 & 45.01 & 2.74 & 39.10 & 50.97 & 45.64 & 1.96 & 38.18 & 52.15 \\
\hline 15 & 168.01 & 69.37 & 142.08 & 539.40 & 156.54 & 10.21 & 133.53 & 248.21 \\
\hline 16 & 53.20 & 2.00 & 49.68 & 57.44 & 52.87 & 1.52 & 49.43 & 57.27 \\
\hline 17 & 78.22 & 3.07 & 72.83 & 83.52 & 78.45 & 2.85 & 70.58 & 87.12 \\
\hline 18 & 121.14 & 8.65 & 105.11 & 143.43 & 122.47 & 8.09 & 101.71 & 147.80 \\
\hline 19 & $21.30 \mathrm{~A}$ & 2.10 & 16.01 & 26.45 & $24.70^{\mathrm{A}}$ & 2.08 & 18.68 & 39.48 \\
\hline 20 & 96.90 & 11.04 & 71.34 & 127.24 & 93.52 & 11.45 & 68.14 & 132.24 \\
\hline
\end{tabular}

Explanations to Table II: index values in rows marked with the same letters differ significantly at: a $-\mathrm{P} \leq 0.05 ; \mathrm{A}-\mathrm{P} \leq 0.01$. 
Table III. Values of the craniometric traits for the nuchal parts of the long-tailed chinchilla skulls.

\begin{tabular}{|c|c|c|c|c|c|c|c|c|}
\hline \multirow[b]{2}{*}{ Trait } & \multicolumn{4}{|c|}{ Group I } & \multicolumn{4}{|c|}{ Group II } \\
\hline & $\mathrm{x}$ & sd & $\min$ & $\max$ & $x$ & sd & $\min$ & $\max$ \\
\hline 36 & $7.65^{\mathrm{A}}$ & 0.36 & 7.10 & 8.67 & $7.98^{\mathrm{A}}$ & 0.40 & 6.80 & 8.97 \\
\hline 37 & $10.04_{\mathrm{A}}$ & 0.73 & 8.38 & 11.73 & $9.37^{\mathrm{A}}$ & 0.57 & 7.89 & 11.29 \\
\hline 38 & $11.77^{\mathrm{A}}$ & 0.88 & 10.10 & 14.26 & $9.94^{\mathrm{A}}$ & 0.71 & 5.48 & 11.53 \\
\hline 39 & $18.03 \mathrm{~A}$ & 1.32 & 15.69 & 20.73 & $19.26^{\mathrm{A}}$ & 0.91 & 16.67 & 21.84 \\
\hline 40 & $31.27 \mathrm{~A}$ & 1.16 & 29.29 & 34.42 & $33.12^{\mathrm{A}}$ & 0.87 & 30.38 & 35.95 \\
\hline 41 & 7.40 & 0.79 & 5.75 & 9.25 & 7.47 & 1.01 & 5.63 & 10.93 \\
\hline 42 & $6.10^{\mathrm{A}}$ & 0.79 & 4.21 & 7.99 & $6.53^{\mathrm{A}}$ & 1.02 & 3.41 & 10.69 \\
\hline 43 & $14.18 \mathrm{~A}$ & 0.80 & 12.46 & 15.99 & $13.41^{\mathrm{A}}$ & 0.67 & 11.67 & 15.58 \\
\hline 44 & $19.85 \mathrm{~A}$ & 0.79 & 18.58 & 21.29 & $19.92^{\mathrm{A}}$ & 0.89 & 18.12 & 26.64 \\
\hline 45 & $24.67 \mathrm{~A}$ & 0.85 & 22.64 & 26.00 & $25.30^{\mathrm{A}}$ & 0.91 & 22.25 & 27.89 \\
\hline 46 & 127.97 & 14.39 & 98.06 & 154.13 & 129.20 & 8.95 & 102.94 & 151.83 \\
\hline 47 & $41.82 \mathrm{~A}$ & 4.45 & 32.62 & 50.23 & $44.64^{\mathrm{A}}$ & 5.80 & 31.88 & 69.98 \\
\hline
\end{tabular}

Explanations to Table III: mean values in rows marked with the same letters differ significantly at $\mathrm{P} \leq 0.01$.

Table IV. Values of the coefficients of correlation for selected long-tailed chinchilla skull traits and cranial indices.

\begin{tabular}{|c|c|c|c|c|c|c|c|c|c|}
\hline \multirow{2}{*}{$\begin{array}{c}\text { Trait } \\
\text { Group II }\end{array}$} & \multicolumn{9}{|c|}{ Group I } \\
\hline & 3 & 4 & 5 & 13 & 14 & Index 16 & Index 17 & Index 18 & Index 19 \\
\hline 3 & & $0.912^{*}$ & $0.538^{*}{ }^{* A}$ & $0.419^{*}$ & $0.719^{* * A}$ & -0.124 & $-0.224^{\mathrm{A}}$ & -0.250 & $0.793^{* * A}$ \\
\hline 4 & $0.705^{*}$ & & $0.810{ }^{*} \mathrm{~A}$ & $0.362^{*}$ & $0.746^{* * A}$ & $-0.169 a$ & -0.117 & $-0.548^{* * a}$ & $0.797 *^{*}$ \\
\hline 5 & $-0.217^{*} *^{* A}$ & $0.482^{* \mathrm{~A}}$ & & $0.213 \mathrm{~A}$ & $0.524 *^{* a}$ & -0.212 & 0.090 & $-0.794^{* *}$ & $0.579^{*}$ \\
\hline 13 & $0.228^{*}$ & $0.346^{*}$ & $0.080 \mathrm{~A}$ & & $0.395^{*}$ & 0.184 & 0.119 & $0.351^{*}$ & $0.573^{*}$ \\
\hline 14 & $0.335^{*}{ }^{* \mathrm{~A}}$ & $0.388^{* * A}$ & $0.168^{*^{\mathrm{a}}}$ & $0.346^{* *}$ & & $0.494 *^{*}$ & $0.424^{*}$ & -0.303 & $0.654 *^{* a}$ \\
\hline Index 16 & $-0.313^{*}$ & $-0.497 *^{* a}$ & $-0.267^{* *}$ & 0.106 & $0.549^{* *}$ & & $0.879^{*}$ & 0.272 & -0.027 \\
\hline Index 17 & $-0.685^{*}{ }^{* A}$ & $-0.376^{*}$ & $0.337^{*}$ & 0.035 & $0.391^{* *}$ & $0.734 *^{*}$ & & -0.030 & -0.073 \\
\hline Index 18 & $0.317^{*}$ & $-0.282^{* \mathrm{*a}}$ & $-0.824^{* *}$ & $0.449^{* *}$ & 0.037 & $0.284^{*}$ & $-0.288^{* *}$ & & -0.176 \\
\hline Index 19 & $0.384^{*}{ }^{* \mathrm{~A}}$ & $0.603^{*}$ & $0.388^{*}$ & $0.691^{* *}$ & $0.427^{*{ }^{* a}}$ & -0.149 & -0.071 & 0.018 & \\
\hline
\end{tabular}

Explanations to Table IV: values of the correlation coefficients marked with * are significant at $\mathrm{P} \leq 0.05$ and with ** are significant at $\mathrm{P} \leq 0.01$; values of the correlation coefficients of the same traits and / or cranial indices marked with the same letters differ significantly at: $\mathrm{a}-\mathrm{P} \leq 0.05 ; \mathrm{A}-\mathrm{P} \leq 0.01$.

Table V. Values of the coefficients of correlation for selected long-tailed chinchilla skull and nuchal parts traits and cranial indices.

\begin{tabular}{|c|c|c|c|c|c|c|c|c|c|c|c|c|}
\hline Group & & & & & & & I & & & & & \\
\hline II & 14 & 16 & 37 & 38 & 40 & 43 & 44 & 45 & 46 & 47 & $19 \diamond$ & $20 \diamond$ \\
\hline 14 & & $.877 *^{\mathrm{A}}$ & $.365 * a$ & $.400 *$ & $.789^{\mathrm{A}}$ & $.714 *^{\mathrm{A}}$ & $.698 *_{\mathrm{A}}$ & $.879 *^{\mathrm{A}}$ & $.819 *_{\mathrm{A}}$ & .193 & $.847 *_{\mathrm{A}}$ & -.074 \\
\hline 16 & $.479 *_{\mathrm{A}}$ & & .333 & $.386^{*}$ & $.876^{* \mathrm{~A}}$ & $.714 * \mathrm{~A}$ & $.655 *_{\mathrm{a}}$ & $.842 * \mathrm{~A}$ & $.848 *_{\mathrm{A}}$ & .186 & $.879 *_{\mathrm{A}}$ & -.142 \\
\hline 37 & $-.056^{a}$ & $.131 *$ & & $.625^{*^{\mathrm{a}}}$ & .236 & .209 & $.463 *_{\mathrm{A}}$ & .315 & $.450^{* \mathrm{a}}$ & $.380^{*}$ & $.420 *_{\mathrm{a}}$ & -.238 \\
\hline 38 & .048 & $.122 *$ & $.253 *_{\mathrm{a}}$ & & .172 & .327 & .335 & .260 & $.469 *_{\mathrm{A}}$ & $.649^{*}$ & $.346 * a$ & .025 \\
\hline 40 & $.419 *_{\mathrm{A}}$ & $.435^{* \mathrm{~A}}$ & .067 & 0078 & & $.571 * \mathrm{~A}$ & $.490 *$ & $.812 * \mathrm{~A}$ & $.707 *_{\mathrm{A}}$ & $-.016 \mathrm{~A}$ & $.824 *_{\mathrm{A}}$ & -.294 \\
\hline 43 & $.123 *_{\mathrm{A}}$ & $.170^{* \mathrm{~A}}$ & -.032 & .082 & $.173^{* \mathrm{~A}}$ & & $.610 *_{\mathrm{A}}$ & $.721 *^{\mathrm{A}}$ & $.829 *$ & .192 & $.694 *_{\mathrm{A}}$ & -.191 \\
\hline 44 & $.245 *_{\mathrm{A}}$ & $.280^{*^{\mathrm{a}}}$ & $-.036 \mathrm{~A}$ & .069 & $.232 *$ & $.152 *^{\mathrm{A}}$ & & $.783^{* \mathrm{~A}}$ & $.742 *_{\mathrm{A}}$ & .272 & $.681 *_{\mathrm{a}}$ & -.220 \\
\hline 45 & $.361 *_{\mathrm{A}}$ & $.406^{* \mathrm{~A}}$ & .085 & -.190 & $.486^{* \mathrm{~A}}$ & $.131 * \mathrm{~A}$ & $.450 *_{\mathrm{A}}$ & & $.820 *_{\mathrm{A}}$ & .112 & $.886 *^{*}$ & -.245 \\
\hline 46 & $.170 *_{\mathrm{A}}$ & $.279 *^{\mathrm{A}}$ & $.053^{\mathrm{a}}$ & $.054^{\mathrm{A}}$ & $.293^{* \mathrm{~A}}$ & $.740 *$ & $.131 *_{\mathrm{A}}$ & $.152 *^{\mathrm{A}}$ & & .187 & $.782 *_{\mathrm{A}}$ & -.242 \\
\hline 47 & .030 & .020 & .197 & $.173 *_{\mathrm{A}}$ & $.074 \mathrm{~A}$ & $.153^{*}$ & .086 & .001 & $.150 *$ & & .153 & $.358^{*}$ \\
\hline 19 & $.460 *_{\mathrm{A}}$ & $.489^{\mathrm{A}}$ & $.033^{\mathrm{a}}$ & $.024^{\mathrm{a}}$ & $.541 * \mathrm{~A}$ & $.208^{\mathrm{A}}$ & $.405 *_{\mathrm{a}}$ & $.681 * \mathrm{~A}$ & $.240 *_{\mathrm{A}}$ & .109 & & -.229 \\
\hline $20 \diamond$ & -.033 & -.002 & .086 & -.009 & -.068 & .021 & -.007 & -.052 & -.016 & $.593 *$ & -.040 & \\
\hline
\end{tabular}

Explanations to Table V: see table IV; $19{ }^{*}$ and $20{ }^{*}$ - indices

No correlation was noted between the viscerocranium index (Zyg-Zyg x 100/Sp-P) and the greatest neurocranium breadth (Eu-Eu) in both chinchilla skull groups, which is a consequence of weak correlation between the neurocranium breadth (Eu-Eu) and its length
(A-Sp). No correlation was observed between the neurocranium index and the viscerocranium index in the museum specimens, too, and a weak correlation between these indices being calculated for the group of farm chinchilla skulls. 


\section{DISCUSSION}

Most traits of the skull of farm chinchillas show statistically significantly higher values when compared to the parameters being determined on the museum skulls, which is probably the result of keeping them for many generations under conditions of the full availability of food with high feeding value. The results being obtained are consistent with the observations made by Crossley \& Miguélez who pointed to significantly longer and broader skulls of farm-reared chinchillas and their different profile when compared to wild chinchillas. Keeping wild animals under conditions of the unlimited availability of high-value fodder results in their earlier maturation and increased growth of cranial and postcranial skeleton elements (O'Regan \& Kitchner). Interpopulation variation of some of the metric traits under analysis may be a significant response to the selection being carried out under specific breeding conditions and obtaining therefore larger individuals (Tamlin et al., 2009). Even wild animals, being caught and kept under very good feeding conditions, respond with increased body size (Poole et al., 1980) and earlier maturation (Altmann et al., 1981; Phillips-Conroy \& Jolly, 1988). Living in the wild is connected with temporary food shortage or intake of not fully valuable fodder, being not consistent with their normal diet. This may incur differences in the skull morphology, even in free-living populations (Zuccarelli).

However, not all traits of the skull of farm chinchillas exceed the corresponding parameters of the museum specimens. Larger value of the length of the viscerocranium base, the length of the maxillary cheektooth row and the greatest palatal breadth (as well as their ranges) in the museum specimens indicates that the reason for these differences may be the type of consumed food. Under natural habitat conditions, fiber constitutes almost $66 \%$ of the chinchilla diet (Cortés et al., 2002). Depending on the season, chinchillas selectively choose different parts of plants or look for nutrients contained in them based on the current requirements being determined by their metabolism (Serra, 1979). High mountain plants, being a habitat for chinchillas (Mohlis), contain, among others, silica and inorganic impurities occurring on their surface or being cell wall incrustation in them (Lanning \& Eleuterius, 1992). Therefore, together with high fiber content, they may play an important role in the physical impact on the palatal skeleton. The effect of considerable daily differences in the air temperature, ranging from $3^{\circ} \mathrm{C}$ to $19^{\circ} \mathrm{C}$ in the coldest months (Martyn, 1995), is not insignificant, either. These daily air temperature differences force chinchillas to continuously look for and eat various food because of thermoregulatory reasons. Under conditions of farm and amateur keeping, a granular feed with the fibre ranging from 12 to $18 \%$ is the main food for chinchillas (Barabasz, 2001), which does not require such hard work of the masticatory apparatus and does not burden a part of head muscles with greater work (Zherebstova, 2012), resulting in significantly smaller $(\mathrm{P} \leq 0.01)$ height of the posterior wall of the neurocranium within Akrokranion-Basion in farm chinchillas when compared to the museum specimens s (Table III).

Thereby, it probably does not have such an effect on the growth of the skull elements being discussed as the fibers being incrusted with silica. The length of the maxillary and mandibular cheek-tooth rows of the museum specimens was significantly larger $(\mathrm{P} \leq 0.01)$ than that of farm chinchilla skulls, despite the fact that other parameters of that part of the skull were significantly larger $(\mathrm{P} \leq 0.01)$ in the skulls of farm-reared chinchillas.

The least breadth between the orbits being measured between the most oral points situated on the anterior margin of the right and left orbits was significantly larger $(\mathrm{P} \leq 0.01)$ in the museum specimens but other parameters describing the cranial breadth, such as the greatest breadth across the praemaxillae, greatest breadth across the orbits, greatest neurocranium breadth or the zygomatic breadth, were significantly larger $(\mathrm{P} \leq 0.01)$ in the skulls of farm chinchillas.

The comparative study of the skull of free-living and farm-reared chinchilla populations being performed complements the broadly described analysis of the effect of keeping animals for generations in the human-created farm environment (O'Regan \& Kitchener; Tamlin et al.). In the farm environment, constant temperature, humidity and photo-period as well as unlimited access to food are the factors contributing to larger body parameters being obtained by animals, which is also observed in the head skeleton.

\section{ACKNOWLEDGEMENTS}

The authors wish to thank the Ministry of Science and Higher Education of the Republic of Poland for funding this study within the research project No. N N311 349337. 
BARANOWSKI, P.; WRÓBLEWSKA, M.; NOWAK, P. \& PEZINSKA, K. Biometría del cráneo de la chinchilla de cola larga (Chinchilla laniger Molina, 1782) salvaje y de granja. Int. J. Morphol., 31(3):1003-1011, 2013.

RESUMEN: El objetivo fue presentar los valores de 47 caracteres métricos y 20 índices craneales del cráneo de 291 chinchillas de granja maduras y comparar estos datos con los determinados sobre 32 cráneos de chinchilla obtenidas desde el Museo de Historia Natural de Londres. Se tomaron mediciones de los parámetros del viscerocráneo, neurocráneo y de la mandíbula. No se observó una distribución normal de estos rasgos. Se calcularon los valores de los coeficientes de correlación de Spearman seleccionado. Se encontró que los rasgos craneales de las chinchillas de granja mostraron valores significativamente superiores $(\mathrm{P} \leq 0,01)$ en comparación con los especímenes de museo. El efecto del entorno agrícola, en el que las chinchillas de granja se habían mantenido durante muchas generaciones, podría ser una razón probable para estas diferencias.

PALABRAS CLAVE: Biometría; Chinchilla; Viscerocráneo; Neurocráneo; Cráneo.

\section{REFERENCES}

Altmann, J.; Altmann, S. \& Hausfater, G. Physical maturation and age estimates of yellow baboons, Papio cynocephalus, in Amboseli National Park, Kenya. Am. J. Primatol., 1:389-9, 1981.

Barabasz, B. Szynszyle - hodowla I uz'ytkownie (Chninchillas breeding and use). Warszawa, PWRiL, 2001.

Baranowski, P.; Wojtas, J.; Cis, J.; Musial, G.; Wróblewska, M. \& Sulik, M. Value of craniometrical traits in Chinchillas (Chinchilla laniger) skulls considering teeth defects. Bull. Vet. Inst. Pulawy, 52(2):271-80, 2008.

Baranowski, P. \& Wojtas, J. Effect of hypertrophic defect on the occurrence of foraminal, shape, and cribrosity features in the cranium and mandible of wild and farm chinchillas (Chinchilla laniger). Bull. Vet. Inst. Pulawy, 55(2):247-60, 2011 a.

Baranowski, P. \& Wojtas, J. The asymmetry of selected foraminal, shape and cribrosity features in the head skeleton of wild and farm chinchillas (Chinchilla laniger). Bull. Vet. Inst. Pulawy, 55(4):787-93, 2011b.

Baranowski, P. Morphometric analysis of early medieval dog skulls from Pomerania allowing for forehead position index and dorsal notch of the foramen magnum. EJPAU, 13(4):16-28, 2010.

Clutton-Brock, J. A natural history of domesticated mammals. London, The Natural History Museum, 1999.

Cortes, A.; Miranda, E. \& Jimenez, J. E. Seasonal foods habits of the endangered long-tailed chinchilla (Chinchilla lanigera): the effect of precipitation. Mamm. Biol., 67(3):167-75, 2002.

Crossley, D. A.; Jackson, A.; Yates, J. \& Boydell, I. P. Use of computed tomography to investigate cheek tooth abnormalities in chinchillas (Chinchilla laniger). J. Small Anim. Pract., 39(8):385-9, 1998.

Crossley D. A. Dental disease in chinchillas in the UK. J. Small Anim. Pract., 42(1):12-9, 2001.
Crossley, D. A. \& Miguélez, M. Skull size and cheek-tooth length in wild-caught and captive-bred chinchillas. Arch. Oral Biol., 46(10):919-28, 2001.

Driesch von den. A. A guide to the measurement of animal bones from archaeological sites. Harvard, Peabody Museum, 1976.

Hoefer, H. L. Chinchillas. Vet. Clin. North Am. Small Anim. Pract., 24(1):103-11, 1994.

Jakubowski, H.; Komosa, M. \& Frackowiak, H. Allometric analysis of cranial parameters of American mink, including bones of masticatory apparatus. EJPAU, 11(3):2, 2008.

Jablonski, R. \& Brudnicki, W. The effect of blood distribution to the brain on the structure and variability of the cerebral arterial circle in musk-rat and in chinchilla. Folia Morphol. (Warz) 43(2):109-14, 1984.

Lanning, F. C. \& Eleuterius, L. N. Silica and ash in seeds of cultivated grains and native plants. Ann. Bot., 69(2):151-60, 1992.

Lavocat R. What is an hystricomorph? In: Rowlands, I. W. \& Weir, B. J. (Eds). The Biology of the Hystricomorph Rodents. London, Academic Press, 1974. pp.7-21.

Mazák, J. H. \& Groves, C. P. A taxonomic revision of the tiger (Panthera Tigris) of Southeast Asia. Mamm. Biol., 71(5):268-87, 2006.

Martyn, D. Klimaty kuli ziemskiej (Climates of the Earth). Warszawa, PWN, 1995.

Mohlis, C. Preliminary information on conservation and management of wild chinchilla in Chile. Bulletin Tech No. 3. Santiago, National Forestry Corporation, 1983.

Milart, Z. Anatomiczne mianownictwo weterynaryjne (Veterinary anatomical nomenclature). Warszawa, PWRiL, 2002. 
O'Regan, H. J. \& Kitchener, A. C. The effects of captivity on the morphology of captive, domesticated and feral mammals. Mamm. Rev., 35(3-4):215-30, 2005.

Onar, V. A morphometric study on the skull of the German shepherd dog (Alsatian). Anat. Histol. Embryol., 28(4):253-6, 1999.

Onar, V.; Belli, O. \& Owen, P. Morphometric examination of red fox (Vulpes vulpes) from the van Yoncatepe necropolis in Eastern Anatolia. Int. J. Morphol., 23(3):253-60, 2005.

Parés, I.; Casanova, P. M.; Sarma, K. \& Jordana, J. On biometrical aspects of the cephalic anatomy of xisqueta sheep (Catalunya, Spain). Int. J. Morphol., 28(2):347-51, 2010.

Phillips-Conroy, J. E. \& Jolly, C. J. Dental eruption schedules of wild and captive baboons. Am. J. Primatol., 15:17-29, 1988.

Poole, W. E.; Carpenter, S. M. \& Simms, N. G. Multivariate analyses of skull morphometrics from the two species of Grey Kangaroos, Macropus giganteus Shaw and M. fuliginosus. Austr. J. Zool., 28(4):591-605, 1980.

Redford, K. H. \& Eisenberg, J. F. Mammals of the Neotropics. Chicago and London, The University of Chicago Press, 1992.

Roskosz, T.; Jablonski, R. \& Wiland, C. The arteries of the brain base in chinchilla, Chinchilla laniger (Molina). Ann. Warsaw Agric. Univ., 14:23-8, 1988.

Sarma, K. Morphological and craniometrical studies on the skull of kagani goat (Capra hircus) of Jammu region. Int. J. Morphol., 24(3):449-55, 2006.

Serra, M. T. Composición botánica y variación estacional de la alimentación de Chinchilla lanigera en condiciones naturales. Ciencias Forestales (Chile), 1(4):11-8, 1979.

Tamlin, A. L.; Bowman, J. \& Hackett, D. F. Separating wild from domestic American mink Neovison vison based on skull morphometrics. Wild. Biol., 15:266-77, 2009.

Zeuner, F. E. A history of domesticated animals. London, Hutchinson, 1963.

Zherebtsova, O. V. The auricle muscles in the relict rodent Laonastes aenigmamus (Rodentia: Diatomyidae). Proc. Zool. Inst. RAS, 316(3):273-81, 2012.

Zhu, L. Craniometrical studies on the skull of tibetan gazelle (Procapra Picticaudata). Int. J. Morphol., 30(1):196-8, 2012.

Zuccarelli, M. D. Comparative morphometric analysis of captive vs. wild African lion (Panthera leo) skulls. Bios, 75(4):131-8, 2004.

\author{
Correspondence to: \\ Prof. Piotr Baranowski, PhD, DSc \\ Department of Animal Anatomy \\ Faculty of Biotechnology and Animal Husbandry \\ Western Pomeranian University of Technology in Szczecin \\ 14 Doktora Judyma St., 71-466 Szczecin \\ POLAND
}

Telephone number: +48 (91) 4496760

Fax number: +48 (91) 4541642

Email address: piotr.baranowski@zut.edu.pl

Received: 19-03-2013

Accepted: 01-07-2013 